\title{
Transformasi perpustakaan untuk generasi millenial menuju revolusi industri 4.0
}

\author{
Catur Dedek Khadijah
}

\begin{abstract}
This article discusses library transformation for the millennial generation towards industrial revolution 4.0. The occurrence of the 4th industrial revolution made technology develop extraordinary, while bringing positive and negative effects to humans. The development of these technologies also influenced the use of social media in the community. So is the library. The collection of digital libraries must also be developed not all books, magazines, or journals but other content that can satisfy the thirst of knowledge for users. The existence of Virtual Reality devices allows libraries to have a collection of libraries that are more interesting and visible to the community. Virtual Reality content is not only available on the internet or content provider services, but can also be independently developed through applications that are often available free on the internet.
\end{abstract}

Keywords: millennial generation; library, industrial revolution 4.0

\section{Pendahuluan}

Perkembangan peradaban dengan revolusi arus informasinya memang mau tak mau membentuk kecenderungan social kaum muda saat ini. Seperti juga yang terjadi pada generasi Y alias generasi millennial, yang mendominasi kaum muda saat ini. Millennial adalah mereka yang kelahirannya antara tahun 1981- 1994 (beberapa yang lain menyebut hingga sebelum tahun 2000).

Kondisi perpustakaan saat ini menunjukkan bahwa inovasi layanan perpustakaan mulai tumbuh dan berkembang secara refleksif terhadap lahirnya generasi millennial. Apalagi saat ini, mau cari apapun sudah langsung menggunakan "Google". Sekali ketik dan klik di google seketika itu juga muncul ribuan hit yang ditemukan. 
Agar perpustakaan tidak di tinggal lari pemustaka dan agar pengunjung tidak semakin berkurang, maka perpustakaan harus tanggap dalam menyambut perubahan ini.

Ketika perpustakaan ingin tetap eksis dalam perpustaran informasi meski memahami karakteristik generasi millennial karena hasil penelitian menunjukkan bahwa 34\% penduduk Indonesia adalah generasi millennial, di perkirakan pada tahun 2025 yang mengisi seluruh instansi baik yang di pemerintahan maupun yang di non pemerintahan akan di kuasai oleh generasi millennial. Perkembangan teknologi komunikasi dan informasi yang begitu cepat jelas berdampak secara signifikan terhadap eksistensi perpustakaan. Sebuah perpustakaan harus tanggap mengenai trend TIK tersebut. Tuntutan kemudahan akses informasi yang serba instan, tepat, dan adanya ketersediaan fasilitas yang di aplikasikan akan mempresentasikan melalui layanan informasi yang di layankan perpustakaan. Perpustakaan harus menyediakan fasilitas berupa wifi area, pw, perpustakaan digital, sehingga memungkinkan pemustaka mudah untuk berselancar mencari informasi melalui internet. Perpustakaan meski cepat tanggap terhadap kebutuhan Generasi Millenial yang haus akan informasi.

Generasi millennial dalam kajian informasi menjadi sesuatu yang sangat menarik bagi pelaku kebijakan untuk mengubah paradigm lama dari perpustakaan. Era generasi millennial saat ini berprinsip bahwa mengakses informasi bias dilakukan dengan mudah dengan berselancar internet kapan dan dimana saja, tidak harus ke perpustakaan. Jadi agar perpustakaan tidak ditinggal pemustakanya, maka perpustakaan harus berbenah dalam penyediaan berbagai sarana prasarana, fasilitas, infrastruktur, dan aspek kebijakan organisasi perpustakaan yang mendukung generasi 
millennial. Selain itu, yang tidak ketinggalan pengelola perpustakaan dan pustakawannya juga harus information literate terhadap adanya pergeseran perubahan generasi millennial dalam kajian informasi saat ini.

Dengan masuknya kita pada era Revolusi Industri 4.0 menyediakan peluang sekaligus tantangan bagi para mahasiswa dan alumni Universitas Terbuka. Peran manusia setahap demi setahap diambil alih oleh mesin otomatis. Akibatnya, jumlah pengangguran semakin meningkat. Hal ini tentu saja akan menambah beban masalah local maupun nasional. Oleh karena iyu, untuk memanfaatkan peluang dan menjawab tantangan revolusi industry 4.0, maka pemustaka wajib memiliki kemampuan literasi data, teknologi untuk meningkatkan skill dalam mengolah dan menganalisis big data untuk kepentingan peningkatan layanan public. Literasi teknologi menunjukkan kemampuan untuk memanfaatkan teknologi digital guna mengolah data dan informasi. Sedangkan literasi manusia wajib dikuasai karena menunjukkan elemen softskill atau pengembangan karakter individu untuk bias berkolaborasi, adaptif dan menjadi arif di era informasi.

Saat ini kita tengah memasuki era revolusi industry 4.0, yaitu era dimana dunia industry digital telah menjadi suatu paradigm dan acuan dalam tatanan kehidupan saat ini. Era revolusi industry 4.0 hadir bersamaan dengan era disrupsi. Untuk menghadapi revolusi industry 4.0 dan era disrupsi diperlukan " literasi baru" selain literasi lama. Literasi lama yang ada saat ini digunakan sebagai model untuk berkiprah di kehidupan masyarakat.

Untuk menghadapi revolusi industry 4.0 atau era disrupsi diperlukan "literasi baru" selain literasi lama. Literasi lama saat ini digunakan sebagai modal untuk berkiprah di kehidupan masyarakat. 
Literasi lama mencakup kompetensi calistung. Sedangkan literasi baru mencakup literasi data, literasi teknologi dan literasi manusia. Literasi data terkait dengan kemampuan membaca, menganalisis dan membuat konklusi berpikir berdasarkan data dan informasi ( big data) yang diperoleh. Literasi teknologi terkait dengan kemampuan ,memahami cara kerja mesin. Aplikasi teknologi dan bekerja berbasis produk teknologi untuk mendapatkan hasil maksimal. Literasi manusia terkait dengan kemampuan komunkasi, kolaborasi, berfikir kritis, kreatif, dan inovatif.

Perpustakaan di era digital harus mampu bertransformasijika ingin relevan dengan zaman. Perpustakaan tidak hanya menjadi tempat koleksi buku dan sumber regferensi, namun sebagai sumber ilmu pengetahuan. Saat ini perpustakaan berangsur menjadi tempat berinteraksi dengan komunitas social serta working space tempat tumbuhnya inovasi baru.

Untuk itu, tugas dunia pendidikan saat ini melalui proses pembelajarannya bukan hanya menekankan pada penguatan literasi baru yang menyatu dalam penguatan kompetensi bidang keilmuan dan keahlian atau profesi.

\section{Pembahasan}

\section{a. Pengertian Generasi Millenial}

Istilah generasi millennial memang sedang akrab terdengar. Istilah tersebut berasal dari millennials yang diciptakan oleh dua pakar sejarah dan penulis Amerika, William Strauss dan Neil Howe dalam beberapa bukunya. Millennial generation atau generasi Y juga akrab disebut generation me atau echo boomers. Secara harfiah memang tidak ada demografi khusus dalam menentukan kelompok generasi yang satu ini. Dapat disimpulkan bahwa yang dimaksud dengan generasi millennial adalah Milenial (juga dikenal sebagai 
Generasi Y) adalah kelompok demografi setelah Generasi X (Gen-X). Ketika mendengar istilah "generasi millennial" pasti yang akan terlintas di benak kita ialah sekelompok remaja tanggung yang selalu memegang smartphone di tangan mereka. Namun, sejatinya generasi yang sering disebut sebagai Generasi Y ini menurut para peneliti sosial dikelompokkan pada generasi yang lahir antara 1980-2000. Jadi bisa dikatakan, orang-orang yang masuk ke dalam kategori ini ialah generasi muda yang saat ini berusia 15-34 tahun.

Menurut Hipwee ada beberapa karakteristik dari generasi millennial antara lain :

1. User Generated Content (UGC) lebih dipercaya oleh kaum millennials ketimbang informasi satu arah

Kini sudah bukan jamannya lagi bagi kaum millennial untuk percaya pada produk iklan atau perusahaan besar. Bisa dikatakan kalau mereka sudah tidak percaya lagi kepada distribusi informasi yang bersifat satu arah. Mereka jauh lebih percaya pada user generated content (UGC) atau konten dan informasi yang dibuat oleh perorangan.

2. Millennial wajib memiliki akun sosial media sebagai alat komunikasi dan pusat informasi

Komunikasi dua arah kini rasanya tidak lagi harus bertatap muka, tapi lewat sosial media pun semua orang bisa tetap saling berkomunikasi tanpa henti. Banyak dari Generasi $\mathrm{Y}$ yang berinteraksi dan menjaga komunikasi lewat text messaging atau juga chatting di dunia maya dengan berbagai platform yang saat ini sudah banyak dijadikan opsi. 
3. Minat membaca secara konvensional kini sudah menurun karena Generasi Y lebih memilih membaca lewat smartphone mereka

Bukannya hilang begitu saja, memang masih banyak orang-orang yang suka membaca buku, tapi tidak lagi di toko buku melainkan lewat e-book. Mereka lebih suka membaca buku secara online karena tak mau repot atau menghabiskan waktu untuk pergi ke toko buku. Perilaku yang sudah mulai tergeser ini juga menjadikan generasi millennials lebih menyukai segala sesuatu secara visual. Mereka menganggap tulisan konvensional hanya akan membuatnya pusing, oleh karena itu mereka lebih memilih melihat sesuatu dengan gambar dan warna yang menarik.

4. Millennial pasti lebih memilih ponsel daripada televisi. Menonton sebuah acara televisi kini sudah tidak lagi menjadi sebuah hiburan karena apapun bisa mereka temukan di telepon genggam

Generasi yang memang lahir di tengah-tengah perkembangan teknologi ini memang sudah tidak lagi menjadikan televisi sebagai media utama mereka. Internetlah yang sangat berperan dalam keberlangsungan hidup kaum ini. The Nielsen Global Survey of E-commerce juga melakukan penelitian terhadap pergeseran perilaku belanja para generasi internet. Penelitian dilakukan berdasar penetrasi internet di beberapa negara.

Nielsen melakukan riset terhadap 30 ribu responden yang memiliki akses internet memadai. Responden tersebut berasal dari 60 negara di Asia Pasifik, Eropa, Amerika Latin dan Utara, serta Timur Tengah. Studi tersebut 
menggambarkan perilaku generasi akrab internet ini memilih jalur daring untuk meneliti dan membeli beragam produk atau jasa dalam memenuhi kebutuhan sehari-hari. Nielsen mencatat, pertumbuhan penetrasi perangkat mobile di kotakota besar Indonesia mencapai 88 persen.

Kepemilikan perangkat mobile menjadi salah satu faktor paling signifikan terhadap perilaku belanja daring. Berdasarkan riset Nielsen tersebut, Indonesia memiliki peringkat teratas secara global dalam hal penggunaan ponsel pintar untuk belanja daring.

Seperti yang diungkapkan oleh Prami Rachmiadi, Chief Digital Content Officer dalam acara Global Entertainment and Media Outlook: 2017 - 2021, "kaum millennial tidak akan pernah bisa lepas dari telepon genggam mereka karena behaviour yang terjadi di tengah masyarakat saat ini ialah harus menjadi orang paling ter-up-to-date. Pergeseran perilaku dari Generasi X dan Generasi Y ini bisa dilihat dari bagaimana cara mereka mengartikan fungsi internet."

5. Millennial menjadikan keluarga sebagai pusat pertimbangan dan pengambil keputusan mereka Berdasarkan survei "Connecting with the Millennials" yang dilakukan Visa pada 2011 lalu, tercatat Indonesia diperkirakan memiliki 5,1 juta millennial. Satu hal yang unik dari survei ini adalah bahwa kaum millennial Indonesia adalah generasi yang paling berbakti pada keluarga. Mayoritas dari mereka, yakni sekitar 91 persen memberikan kontribusi finansialnya kepada orangtua.

Dari ke lima ciri di atas dapat di simpulkan bahwa Generasi milenial melibatkan google sebagai keluarga untuk pusat 
pertimbangan mereka dalam mengambil keputusan. Hal ini terjadi karena dari google dapat ditemukan berbagai pendapat dari seluruh dunia sehingga menjadi adviser mereka.

\section{Tantangan Bagi Generasi Millenial}

Generasi milenial adalah generasi yang sangat mahir dalam teknologi. Dengan kemampuannya di dunia teknologi dan sarana yang ada, generasi ini memiliki banyak peluang untuk bisa berada jauh di depan dibanding generasi sebelumnya. Namun sayangnya, dari beberapa statistik yang saya baca, dikatakan bahwa generasi milenial cenderung lebih tidak peduli terhadap keadaan sosial, termasuk politik dan ekonomi. Mereka cenderung lebih fokus kepada pola hidup kebebasan dan hedonisme. Mereka cenderung mengingkan hal yang instant dan tidak menghargai proses.

Di era ini segala sesuatu bergerak dengan cepat, dunia menjadi tanpa batas, informasi dapat diperoleh dimana saja dan dari siapa saja. Generasi masa kini harus berusaha dan mampu menjadi bijak terutama dalam penggunaan media sosial. Media sosial ini mirip dengan politik, tergantung bagaimana kita menggunakannya. Kita bisa berguna dan bertambah pintar apabila menggunakan media sosial dengan benar, tapi kita juga bisa menjadi penyebar hoax dan menjadi bodoh apabila kita menggunakan media sosial dengan tidak benar.

Di era ini dengan segala kecanggihan teknologi, tingkat persaingan juga semakin tinggi. Kualitas dan kinerja manusia juga dituntut menjadi semakin tinggi. Generasi masa kini harus mampu beradaptasi dengan cepat, belajar dan menjadi lebih baik dengan cepat serta melakukan navigasi yang lincah dan tepat untuk dapat memecahkan setiap masalah. Kreatifitas dan Apabila tidak, dalam beberapa tahun ke depan mungkin posisi kita sudah digantikan oleh 
robot atau program komputer. Di Indonesia, ada sekitar 81 juta penduduk yang termasuk dalam generasi milenial. Berarti sekitar hampir 32\% dari total populasi di Indonesia.

\section{b. Peran Perpustakaan di Era Digital}

Misi perpustakaan yang utama dalam mencerdaskan bangsa adalah dengan menyediakan layanan informasi terbaik bagi penggunanya. Seiring berkembangnya teknologi, peran perpustakaan semakin tergeser untuk pemenuhan kebutuhan informasi.

Tak bisa dipungkiri, bahwa masyarakat luas sekarang telah beralih atau lebih banyak menggunakan internet untuk mendapatkan informasi daripada datang ke perpustakaan.

Tugas mempertahankan perpustakaan menjadi lebih berat karena harus bersaing dengan sistem penyediaan informasi yang berkembang pesat bersama dengan teknologi saat ini. Para pustakawan harus lebih aktif untuk menciptakan layanan perpustakaan yang modern dan ideal serta diminati oleh masyarakat luas.

Di era digital, berbagai macam bentuk informasi sudah disajikan dalam format digital yang dapat dengan mudah diproduksi dan didistribusikan kepada masyarakat melalui bantuan teknologi informasi internet. Teknologi ini semakin berkembang dengan pesat.

Karena kemudahannya, tidak sedikit masyarakat khususnya mahasiswa yang memilih untuk mengunduh dan memiliki buku digital (e-book) untuk dibaca di rumah daripada membeli bukubuku yang tersedia di toko atau meminjam buku-buku di perpustakaan. Hal ini memaksa perpustakaan untuk menawarkan sesuatu yang baru dan unik agar tidak ditinggalkan oleh masyarakat. 
Peran perpustakaan, khususnya, di era digital seperti saat ini harus dikembangkan tidak hanya menjadi tempat untuk kegiatan membaca dan meminjam buku saja tapi juga menjadi tempat untuk beragam aktivitas lainnya yang didukung dengan lingkungan perpustakaan yang menarik dan nyaman serta berbasis teknologi.

Implementasi TIK secara integral dan komprehensif di perpustakaan seharusnya tidak diposisikan sebagai momok. Tetapi, teknologi itu harus ditempatkan sebagai peluang dan fasilitas bagi perpustakaan dan pustakawan untuk memberikan layanan yang terbaik dan lebih berkualitas. Bahkan, kehadiran teknologi itu seharusnya menjadi media transformasi dan revitalisasi penyelenggaraan perpustakaan

Ada banyak fakta dan pengalaman yang menunjukkan begitu besar peran dan kontribusi TIK terhadap terjadinya efisiensi dan efektivitas penyelenggaraan perpustakan. Best practices (paraktikpraktik terbaik) dan kisah sukses banyak perpustakaan dari berbagai negara dapat menjadi sumber inspirasi bagi para pengelola untuk melakukan hal serupa guna menghadirkan perpustakaan yang lebih sesuai dengan kebutuhan zama sekaligus hal itu akan mengangkat citra dunia perpustakaan Indonesia pada aras yang lebih terhormat. Pemanfaatan TIK secara luas dalam kehidupan sehari-hari masyarakat seharusnya menjadi pemicu dan pemacu bagi perpustakaan untuk menerapkan teknologi serupa di dalam penyeleng-garaan perpustakaan. Diyakini bahwa bila TIK eksis dalam penyelenggaraan perpustakaan, maka akan berdampak positif terhadap seluruh aspek perpustakaan. Hal itu setidaknya merupakan jawaban terhadap berbagai perkembangan dan trend yang terjadi saat ini dan nanti. Bila kita merujuk pada terminologi yang dinyatakan oleh Wastawy (2007) tentang The Open Revolution, maka 
tidak pilihan lain bagi perpustakaan kecuali melakukan berbagai perubahan di perpustakaan untuk merelevansikan dengan perkembangan, terutama perkembangan TIK. The Open Revolution Wastawy meliputi:

1. Open Research

2. Open Reference

3. Open Aggregation

4. Open Storage

5. Open Course

6. Open Content

7. Open Source

8. Open Standards

9. Open Archives

10. Open Text

11. Open Linking

12. Open Design

13. Open Access

Perubahan di dunia perpustakaan perguruan tinggi dinyatakan pula oleh Midda dkk (2009) yang memokuskan pada perbandingan antara fungsi-fungsi perpustakaan perguruan tinggi beberapa tahun sebelumnya dengan perpustakaan yang berbasis teknologi informasi seperti yang eksis saat ini. Konsekuensi lain dari perkembangan TIK di samping adanya peran baru perpustakaan pada era digital ini adalah munculnya ekspektasi baru pemakai terhadap layanan dan fasilitas yang harusnya ada setiap perpustakaan. Menurut hemat penulis, perubahan ekspektasi itu setidaknya karena pemakai perpustakaan atau masyarakat pada umumnya terbiasa telah terbiasa memanfaatkan TIK dalam dalam kehidupan sehari-harinya. Mereka mendapatkan banyak kemudahankemudahan dalam 
memanfaatkan teknologi itu. Interaksi dan komunikasi setiap orang saat ini lebih didominiasi dengan menggunakan produk-produk TIK. Suatu hal logis kalau kemudian pemakai perpustakaan pada era ini juga mengharapkan penyelenggaraan perpustakaan berbasis TIK sebagaiamana mereka gunakan dalam kehidupan sehari-harinya.

Sejalan dengan pendapat Obe (2009) tentang perubahanperubahan yang terjadi sebagai dampak kemajuan TIK saat ini, Sharma (2005) juga menyatakan adanya sejumlah perubahan penting terhadap penyelenggaraan perpustakaan pada era digital seperti sekarang ini. Sebagai respons terhadap kondisi dan situasi tersebut di atas, perpustakaan harus melakukan berbagai penyesuaian (adjustment) agar perpustakaan tetap eksis, survive, dan relevan dengan tuntutan dan ekspekstasi masyarakat pemakai saat ini. Penyesuaian dilakukan untuk melaksanakan sejumlah peran baru perpustakaan yang berbeda secara signifikan dari peran yang selama ini dilakoni. Pada era ini perpus-takaan dapat berperan antara lain sebagai: perantara \& agregator (kolektor), penerbit, institusi riset.

Konsekuensi lain dari perkembangan TIK di samping adanya peran baru perpustakaan pada era digital ini adalah munculnya ekspektasi baru pemakai terhadap layanan dan fasilitas yang harusnya ada setiap perpustakaan. Menurut hemat penulis, perubahan ekspektasi itu setidaknya karena pemakai perpustakaan atau masyarakat pada umumnya terbiasa telah terbiasa memanfaatkan TIK dalam dalam kehidupan sehari-harinya. Mereka mendapatkan banyak kemudahankemudahan dalam memanfaatkan teknologi itu. Interaksi dan komunikasi setiap orang saat ini lebih didominiasi dengan menggunakan produk-produk TIK. Suatu hal logis kalau kemudian pemakai perpustakaan pada era ini juga 
mengharapkan penyelenggaraan perpustakaan berbasis TIK sebagaiamana mereka gunakan dalam kehidupan sehari-harinya.

Tidak hanya sampai di situ, TIK juga telah melahirkan generasi baru pada abad ini Generasi Milenial (The Millennial Generation). Sementara, Chen (2009) mengistilahkannya sebagai Generation G (Google Generation). Generasi milenial adalah generasi yang mengikuti dan identik dengan perkem-bangan TIK. Dalam konteks informasi, mereka memiliki karakteristik antara lain:

1. Mereka memperoleh informasi secara online

2. Mereka mendapatkan informasi dan konten secara gratis

3. Mereka sendiri mengelola konten dalam jumlah besar

4. Mereka sendiri yang membuat, mengumpulkan, dan menyesuaikan informasi

5. Mereka bertindak sebagai distributor sekaligus sebagai pemasar informasi

6. Mereka selalu terkoneksi

7. Mereka mendapatkan informasi secara cepat 8. Mereka selalu On.

Karakteristik generasi milenial di atas mengindikasikan begitu dominanya peman-faatan TIK dalam kehidupannya, tak terkecuali masyarakat Indonesia. Dalam konteks Indonesia, dunia perpustakaan kita harus lebih awas dan mumpuni dalam banyak aspek, terutama menyediakan layanan berbasis TIK plus fasilitas perpustakaan terkait dengan teknologi itu. Dengan demikian, perpustakaan akan semakin mengecilkan peluang untuk ditinggal pemakainya. Potensi dan peluang perpustakaan ditinggalkan pemakainya di tengah kecanggihan TIK merupakan sesuatu yang sangat logis. Tidak dipungkiri bahwa kemampuan dan keperkasaan internet saat ini sebagai sumber informasi yang hampir tak 
tertandingi. Bahkan, internet dapat memerankan hampir seluruh peran perpustakaan konvensional selama ini. Keunggulan lain, internet memfasilitasi ketersediaan akses sumber-sumber informasi kapan dan di mana saja, format dan ragam informasi, internet sebagai alat komunikasi efisien dan efektif, dan keunggulankeunggulan lainnya. Faktafakta tentang keunggulan yang dimiliki internet itu bisa menjadi motif dan alasan logis bagi pemakai untuk lebih memilih menggunakan internet dari pada perpustakaan.

\section{Transformasi Perpustakaan Menuju Revolusi Industri 4.0}

Perpustakaan di perguruan tinggi dituntut untuk segera melakukan transformasi agar bisa beradaptasi dan berevolusi menghadapi pendidikan digital dan revolusi industri 4.0. Sebab di era tersebut perpustakaan tidak bisa lagi dikelola secara konvensional.

Transformasi menjadi satu hal penting bagi perpustakaan di perguruan tinggi. Sebab, perpustakaan perguruan tinggi merupakan bagian integral dari kegiatan pendidikan, dan pengabdian kepada masyarakat atau tri dharma perguruan tinggi. Serta berfungsi sebagai pusat sumber pembelajaran seluruh civitas akademika di perguruan tinggi."Jadi walaupun zaman terus berkembang, perpustakaan senantiasa memegang peranan penting sebagai sumber ilmu pengetahuan. Jangan sampai nantinya perpustakaan terlindas perkembangan zaman,

Perpustakaan ke depannya tidak hanya menjadi tempat berkumpul untuk membaca buku ataupun mencari informasi, namun perpustakaan dapat menjadi working space tempat munculnya inovasi-inovasi baru. Perpustakaan juga dapat menjadi suatu virtual office. 
Perpustakaan telah mengalami beberapa kali evolusi dalam perkembangannya. Jika semula perpustakaan berfokus pada koleksi pustaka dan layanan, kini telah bergeser pada nilai tambah (Noh, 2015). Dengan demikian, perkembangan perpustakaan pada tahapan berikutnya sangat mungkin terjadi dan bisa diciptakan. Hal ini diperlukan untuk menyesuaikan dengan perkembangan pemustaka dan perkembangan teknologi informasi. Harapannya, berbagai penyesuaian dapat membuat perpustakaan semakin berharga dan memberi dampak yang semakin besar bagi dunia pendidikan.

Keberadaan kecerdasan buatan atau artificial intelligence (AI), big data, internet of things(loT), layanan berbasis cloud, dan alat-alat cerdas, sebagai ciri dari Revolusi Industri 4.0 akan membuat banyak perubahan dunia pendidikan (Grewal, Motyka, \& Levy, 2018). Akibatnya, pengelola perpustakaan di berbagai belahan dunia menebak-nebak terobosan berikutnya yang harus dilakukan.

Hal tersebut tidak ada yang salah. Hanya saja, melihat kebutuhan nyata yang ada di dalam dunia pendidikan justru harus menjadi fokus dalam pengembangan perpustakaan. Teknologi informasi dapat mewujudkan apabila kebutuhan dan solusi yang dirancang sudah mulai terbentuk.

Namun berbicara mengenai perpustakaan, tidak hanya membahas mengenai koleksi pustaka yang dimiliki dan pengembangan koleksi pustaka dalam bentuk digital. Masih ada pustakawan yang dapat menjadi nilai jual dan penguat dari keberadaan perpustakaan. Apalagi saat ini koleksi buku ataupun buku elektronik semakin mudah didapatkan dengan prosedur peminjaman dan pengembalian yang lebih mudah dan mandiri, bahkan tidak merepotkan peminjam. 


\section{Perpustakaan Inovatif}

Tuntutan dari kemajuan teknologi informasi di dunia perpustakaan saat ini membuat layanan perpustakaan juga berubah dari semula mengandalkan lokasi, luasan ruang, kelengkapan koleksi, atau sistem informasi; ke perpustakaan yang dapat menyediakan layanan yarig dapat menjawab kebutuhan dunia pendidikan dalam hal menemukan rujukan berkualitas, penulisan rujukan yang baik, bahkan juga mengantisipasi plagiasi (Sanjaya, 2018).

Apabila aktivitas ini dilakukan dengan baik maka eksistensi perpustakaan pada masa depan akan tetap terjaga. Apalagi jika perpustakaan juga menjadi fasilitator bagi pengembangan kontenkonten lokal yang akan menjadi koleksi di perpustakaan terkait Konten lokal meliputi artikel ilmiah ataupun dokumentasi pembelajaran di perguruan tinggi masing-masing. Pengelolaan Massive Open Online Course (MOOC) bukan tidak mungkin akan lebih meningkatkan nilai tambah dan kecepatan berkembangnya jika ditangani oleh perpustakaan.

Koleksi pustaka digital juga harus dikembangkan tidak sematamata buku, majalah, ataupun jumal tetapi konten lain yang dapat memuaskan dahaga pengetahuan bagi pemustaka. Keberadaan perangkat Virtual Reality memungkinkan perpustakaan untuk mempunyai koleksi pustaka yang lebih menarik dan tampak nyata bagi masyarakat (Goan \& Liang, 2015). Konten Virtual Reality bukan hanya tersedia di internet ataupun jasa penyedia konten tersebut, namun juga dapat dikembangkan sendiri melalui aplikasi yang sering tersedia gratis di internet.

Pengembangan asisten virtual yang cerdas dan membantu pemustaka mendapatkan kebutuhannya juga perlu dilakukan agar 
tetap menarik pemustaka dari generasi muda. Untuk itu, perpustakaan tidak boleh berhenti berinovasi, ke depan, bisa menjadi tempat untuk menemukan pengalaman yang lebih kaya bagi pemustakanya. Dengan menjadi perpustakaan inovatif, perpustakaan akan selalu hidup, memberikan pengalarnan baru dan menghasilkan nilai tambah bagi orang-orang di sekitarnya dan menjadi paru-paru pengetahuan di dunia pendidikan.

Karakteristik di era revolusi industri tersebut meliputi digitalisasi, optimation dan cutomization produksi, otomasi dan adaptasi, interaksi antara manusia dengan mesin, value added services and business, automatic data exchange and communication, serta penggunaan teknologi informasi. Oleh karen itu, dunia pendidikan dan industri harus mmpu mengembangkan starategi transformasi industri dengan mempertimbangkan sektor sumber daya manusia yang memiliki kompetensi dibidangnya. Dan revolusi industry akan merubah segala aspek kehidupan, seperti halnya ekonomi, pekerjaan, dan tata kehidupan sosial masyarakat

Menurut Menteri Riset, Teknologi dan Pendidikan Tinggi (Menristekdikti) Mohammad Nasir menyampiakan bahwa tantangan revolusi industri 4.0 harus direspon secara cepat dan tepat oleh seluruh pemangku kepentingan di lingkungan Kemenristekdikti agar mampu meningkatkan daya saing bangsa Indonesia ditengah persaingan. Untuk itu Pendidikan Tinggi wajib merumuskan kebijakan strategis dalam berbagai aspek mulai dari kelembagaan, bidang studi, kurikulum, sumber daya, serta pengembangan cyber university, dan risbang hingga inovasi.

Ada lima elemen penting yang harus menjadi perhatian dan akan dilaksanakan oleh Kemenristekdikti untuk mendorong pertumbuhan ekonomi dan daya saing bangsa di era Revolusi Industri 4.0, yaitu: 
1. Persiapan sistem pembelajaran yang lebih inovatif di perguruan tinggi seperti penyesuaian kurikulum pembelajaran, dan meningkatkan kemampuan mahasiswa dalam hal data Information Technology (IT), Operational Technology (OT), Internet of Things (IoT), dan Big Data Analitic, mengintegrasikan objek fisik, digital dan manusia untuk menghasilkan lulusan perguruan tinggi yang kompetitif dan terampil terutama dalam aspek data literacy, technological literacy and human literacy.

2. Rekonstruksi kebijakan kelembagaan pendidikan tinggi yang adaptif dan responsif terhadap revolusi industri 4.0 dalam mengembangkan transdisiplin ilmu dan program studi yang dibutuhkan. Selain itu, mulai diupayakannya program Cyber University, seperti sistem perkuliahan distance learning, sehingga mengurangi intensitas pertemuan dosen dan mahasiswa. Cyber University ini nantinya diharapkan menjadi solusi bagi anak bangsa di pelosok daerah untuk menjangkau pendidikan tinggi yang berkualitas.

3. Persiapan sumber daya manusia khususnya dosen dan peneliti serta perekayasa yang responsive, adaptif dan handal untuk menghadapi revolusi industri 4.0. Selain itu, peremajaan sarana prasarana dan pembangunan infrastruktur pendidikan, riset, dan inovasi juga perlu dilakukan untuk menopang kualitas pendidikan, riset, dan inovasi.

4. Terobosan dalam riset dan pengembangan yang mendukung Revolusi Industri 4.0 dan ekosistem riset dan pengembangan untuk meningkatkan kualitas dan kuantitas riset dan pengembangan di Perguruan Tinggi, Lembaga Litbang, LPNK, Industri, dan Masyarakat. 
5. Terobosan inovasi dan perkuatan sistem inovasi untuk meningkatkan produktivitas industri dan meningkatkan perusahaan pemula berbasis teknologi.

\section{Penutup}

Revolusi industri 4.0 ditandari dengan cyber-physical, karena industri mulai menyentuh dunia virtual, membentuk konektivitas mausia, mesin dan data, dan semuanya ada di mana-mana. Kondisi obesitas informasi dan tsunami informasi membuat pustakawan harus upgrade terhadap teknologi yang terjadi untuk membuat diri kita menjadi lebih baik.

Di era serba digital saat ini, perpustakaan harus bisa menjangkau seluruh lapisan masyarakat melalui penggunaan teknologi informasi, sehingga dampak positifnya terhadap pengembangan sumber daya manusia dan kesejahteraan masyarakat bisa dirasakan.

Perpustakaan tidak hanya menyediakan koleksi, tetapi perpustakaan sudah siap untuk menyediakan fasilitas yang memadai. Perpustakaan tidak hanya menjadi pusat belajar, tetapi tempat berkumpulnya komunitas tertentu yang sudah semakin marak di era millennial ini. Peran pustakawan di tuntut untuk lebih dapat berinovasi, kreatif, dan tidak lelah untuk terus belajar dalam menggali informasi yang dibutuhkan oleh pemustaka.

\section{Daftar Pustaka}

Achmad, Et all. (2012). Layanan Cinta: Perwujudan Layanan Prima Perpustakaan. Jakarta: Sagung Seto.

Midda, dkk. (2009). Changes of Activities in Academic Library System in India. International Conference on Academic Libraries (ICAl2009). Delhi, India: Delhi University Library Sistem, 2009.

Obe, J.D. (2009). Transformation Through Action: Making the Case for Libraries in the Knowledge Economy. International Conference 
on Academic Libraries (ICA12009). Delhi, India: Delhi University Library Sistem, 2009.

Salmubi, Jupiter. (2016). Lanskap baru perpustakaan dan pustakawan pada era digital Volume XV No.1

Wastawy, S. (2007). Where do We Go from Here? Librarians Role in the Era of Digital Information.

www.ristekdikti.go.id/pengembangan-iptek-dan-pendidikan-tinggi-diera-revolusi-industri-4-0 (diakses jum'at, 26 Oktober 2018. Pukul. 15.00 WIB).

http:// serikatnews.com/peran-dan-tantangan-pemuda-di-eragenerasi-milenial/ Dini Shanti Purwono, SH, LL.M. (diakses Senin, 29 Oktober 2018. Pukul. 13.00 WIB). http://www.republika.co.id/berita/koran/inovasi/16/12/26/ ois64613-mengenal-generasi-millennial (diakses Selasa, 30 Oktober 2018. Pukul.

17.00

WIB) 